\title{
A FIELD STUDY OF ROUGH SHORE-FAST SEA ICE
}

\author{
By Thomas O'D. Hanley, S. J. \\ (Campion College, University of Regina, Regina, Saskatchewan S4S OA2, Canada)
}

\begin{abstract}
During December 1973 the initial smooth ice cover on the Chukchi Sea near Barrow, Alaska, broke away from the shore during a period of strong wind and was replaced by a cover of broken, rafted ice which remained for the rest of the winter. Cores pulled from this cover were examined visually, and the salinity and density of sections of the cores were measured. Temperatures at several depths in the ice were recorded continuously, and these are presented near the date when the temperature gradient changed sign. Despite large deviations probably due to the irregularity of the ice cover, thickness and salinity followed the patterns seen by other observers.
\end{abstract}

Résumé. Étude d'un champ rugueux de glace de mer échouée. Pendant le mois de decembre 1973, la couche de glace qui avait recouvert la mer Chukchi près de Barrow, Alaska, s'est détachée du rivage au cours d'une période vent fort, et a été remplacée par un couvert de brash et de glace hummockée, qui a duré le reste de l'hiver. Des échantillons recueillis de ce couvert ont été examinés visuellement, et la salinité et la densité de certaines tranches des échantillons ont été mesurées. La température de la glace á plusieurs pro-

\section{INTRODUCTION}

In a recent paper on sea ice, Nakawo and Sinha (1981) pointed out the paucity of studies relating the ice quality to growth conditions in the field. As a result of that remark this paper has grown out of a record of ice cores and other data gathered in 1974 near Barrow, Alaska, during a winter when the ice cover was formed from broken ice and slush driven by a wind averaging about $35 \mathrm{miles} / \mathrm{h}(56 \mathrm{~km} / \mathrm{h}, 16 \mathrm{~m} / \mathrm{s})$ as recorded by the National Weather Service office in Barrow. The resulting jumbled and rafted field of ice is a significant feature of this paper.

Although such jumbled and rafted ice is quite common in areas of pack ice, it has apparently been little studied. This paper presents a set of observations on the temperature, growth rate, salinity, and density of such ice.

\section{EXPERIMENTAL DETAILS}

Ice cores of diameter $75 \mathrm{~mm}$ ( 3 inches) were extracted by means of a SIPRE corer. Slices about $2 \mathrm{~cm}$ thick were cut from them, usually in adjacent pairs, at intervals of about $10 \mathrm{~cm}$, and stored in polyethylene sample bags. Alternate slices were allowed to melt, and the salinity of the melt water was measured by means of a conductivity-type salinity meter, with temperature compensation.

The overall density of the other slices was measured by weighing each sample in air and in kerosene which had a relative density of 0.806 . This value was ascertained by weighing a metal cylinder of mass near $1 \mathrm{~kg}$ in air, in distilled water, and in the kerosene; the relative density of the kerosene was then

$$
d=\frac{\text { weight in air - weight in kerosene }}{\text { weight in air - weight in water }} \text {. }
$$

Some of the ice samples which contained many air bubbles floated in the kerosene. In these cases, when the two faces of the ice disk were smooth and parallel it was possible to measure the thickness of ice which projected above the water surface and calculate the relative density from this measurement. In other cases fondeurs a èté enrégistrée sans arrêt, et nous présentons ces températures pour la période où le sens du gradient de température s'est inversé. L'épaisseur et la salinité étaient conformes à ce qu'ont trouvé d'autres chercheurs, bien que nous ayons trouvé des déviations assez larges, qui sont expliquées par la rugosité du couvert de glace.

Zusammenfassung. Eine Felduntersuchung von rauhem, küstenfestem Eis. Im Dezember 1973 brach die ursprünglich glatte Eisdecke der Chukchi-See bei Barrow, Alaska, während einer Periode starken Windes von der Küste ab und wurde durch eine Decke zerbrochenen, zusammengeschobenen Eises ersetzt, die für den Rest des Winters erhalten blieb. Bohrkerne aus dieser Decke wurden visuell untersucht, ihr Salzgehalt und die Dichte von Abschnitten der Kerne wurden gemessen. Temperaturen in verschiedenen Tiefen des Eises wurden laufend aufgezeichnet; eine Auswahl daraus von dem Zeitpunkt, wo der Temperaturgradient sein Vorzeichen änderte, wird hier wiedergegeben. Trotz erheblicher Abweichungen, wahrscheinlich verursacht durch die Unregelmässigkeiten der Eisdecke, stimmten Dicke und Salzgehalt gut mit Beobachtungen von anderer Seite überein.

a metal cylinder was attached to the sample to submerge it, and weights were recorded with the metal cylinder in the kerosene and the ice sample in air, and again with both articles submerged in the kerosene. All of these measurements were made in an unheated building (at -10 to $-20^{\circ} \mathrm{C}$ ) to prevent melting of the ice samples.

About three metres from the area from which most of the ice cores were taken, a string of thermistors was frozen into the ice with one in the air just above the ice and the others at depths of $0.2 \mathrm{~m}$, $0.50 \mathrm{~m}$, and $0.80 \mathrm{~m}$. A cable connected the thermistor to a telethermometer and chart recorder located in a heated cabin on the shore. The temperatures were recorded continuously from 7 February 1974 until 8 June 1974.

A study of ice fabrics from the cores was begun, but was curtailed before useful results were obtained, by a fire which destroyed the commissary building and a refrigerator which contained core samples and facilities for preparing and studying thin sections.

\section{RESULTS AND DISCUSSION}

1. General natiose of the ice

By mid-December the landfast ice near the Naval Arctic Research Laboratory (NARL) between the town of Barrow and Point Barrow in Alaska extended about $1.2 \mathrm{~km}$ from shore with new ice beyond that; at $1.2 \mathrm{~km}$ from the shore its thickness was about $0.7 \mathrm{~m}$. Its upper surface was smooth, with only occasional ridges about 10 to $50 \mathrm{~mm}$ in height. On 29 December this ice broke away at the tidal crack near the shore. Throughout that morning brash and slush moved toward the northeast along the shore, carried by a wind whose average speed was about $13 \mathrm{miles} / \mathrm{h}(21 \mathrm{~km} / \mathrm{h}, 6 \mathrm{~m} / \mathrm{s})$.

The pack ice returned a day or two later, driven by winds of up to $55 \mathrm{miles} / \mathrm{h}(89 \mathrm{~km} / \mathrm{h}, 25 \mathrm{~m} / \mathrm{s})$, crushing in toward the shore and producing about $2 \mathrm{~km}$ of hummocked fast ice with a well-defined barrier ridge at about the $20 \mathrm{~m}$ depth contour. By mid-January it was judged safe to travel on this ice, and a set of stress transducers was installed in a small pan surrounded by the hummock field, about $30 \mathrm{~m}$ offshore from a radar hut located near the north-west corner of the NARL property (Fig. 1). The depth of the water 


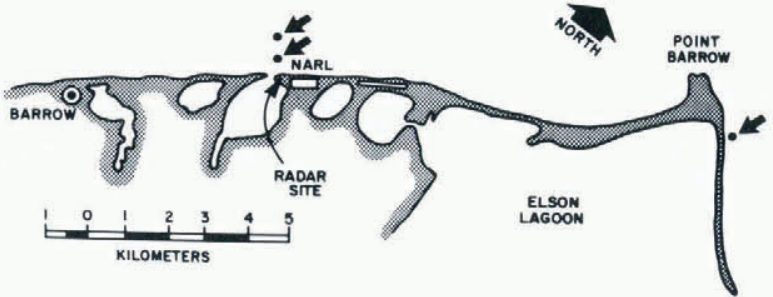

Fig. 1. Location of core sites near Barrow, Alaska, January to April 1974.

at this location was $2.2 \mathrm{~m}$. It was from this pan that all but one of the ice cores to be reported in detail were taken; the last core to be reported was taken

from a region of relatively smooth ice $100 \mathrm{~m}$ offshore and $1.7 \mathrm{~km}$ east of Point Barrow (see Fig. 1 ). A few measurements are also given from one last core extracted on 30 April from a broad pan about $1.1 \mathrm{~km}$ west of NARL.

It is important to notice the conditions under which this ice cover was formed. The hummocked ice was much rafted and was grounded in many places out to the $15 \mathrm{~m}$ depth contour, about $1.6 \mathrm{~km}$ from the shore, so that the bottom surface of the ice must have been as rough as the upper surface. Slush had moved into the crevices of the bottom surface of the ice, and had packed so firmly that on 24 January and 8 February the plummet of a depth gauge was unable to drop through the congested slush. As congelation ice developed under the surface layers, the lower surface of the ice seems to have become smoother except in regions where an ice keel was grounded.

\section{Visual inspection of cores}

Most of the information recorded in a log about the ice cores is summarized in Figure 2, which shows the eight cores whose salinity and density will be discussed later and, for a comparison of thickness and of the position of breaks, one core cut from an ice pan about $1.7 \mathrm{~km}$ offshore from the radar hut and west of NARL, for which no detailed analysis was made. It must be kept in mind that the characteristics listed in the legend of Figure 2 are estimates made from visual observations. The visual distinction between snow-ice and slush-ice is tenuous, the estimate being dependent on the amount of air which appeared to be entrained in the ice. Sections designated by a blackened square were probably columnar ice clouded with air bubbles; sometimes a dense cloud in the ice was recorded simply as "white". Often inclusions of slush-ice or snow-ice appeared in a section which was clear for the most part. The "long bubbles" may be those characteristic of air occluded within growing columnar ice, but sometimes appeared to be brine cells drained of their brine, especially in the core taken in late April from near Point Barrow. Whereas snow-ice is formed from snow impregnated with water and subsequently frozen, "compacted snow" refers to sections rigid enough to hold together when cut with a saw, but still air-filled and easily crumbled. In at least one case, the uppermost section (at $0.39 \mathrm{~m}$ above the free water surface) in core No. 5, the pores were connected so that they readily filled with kerosene during the measurement of density, resulting

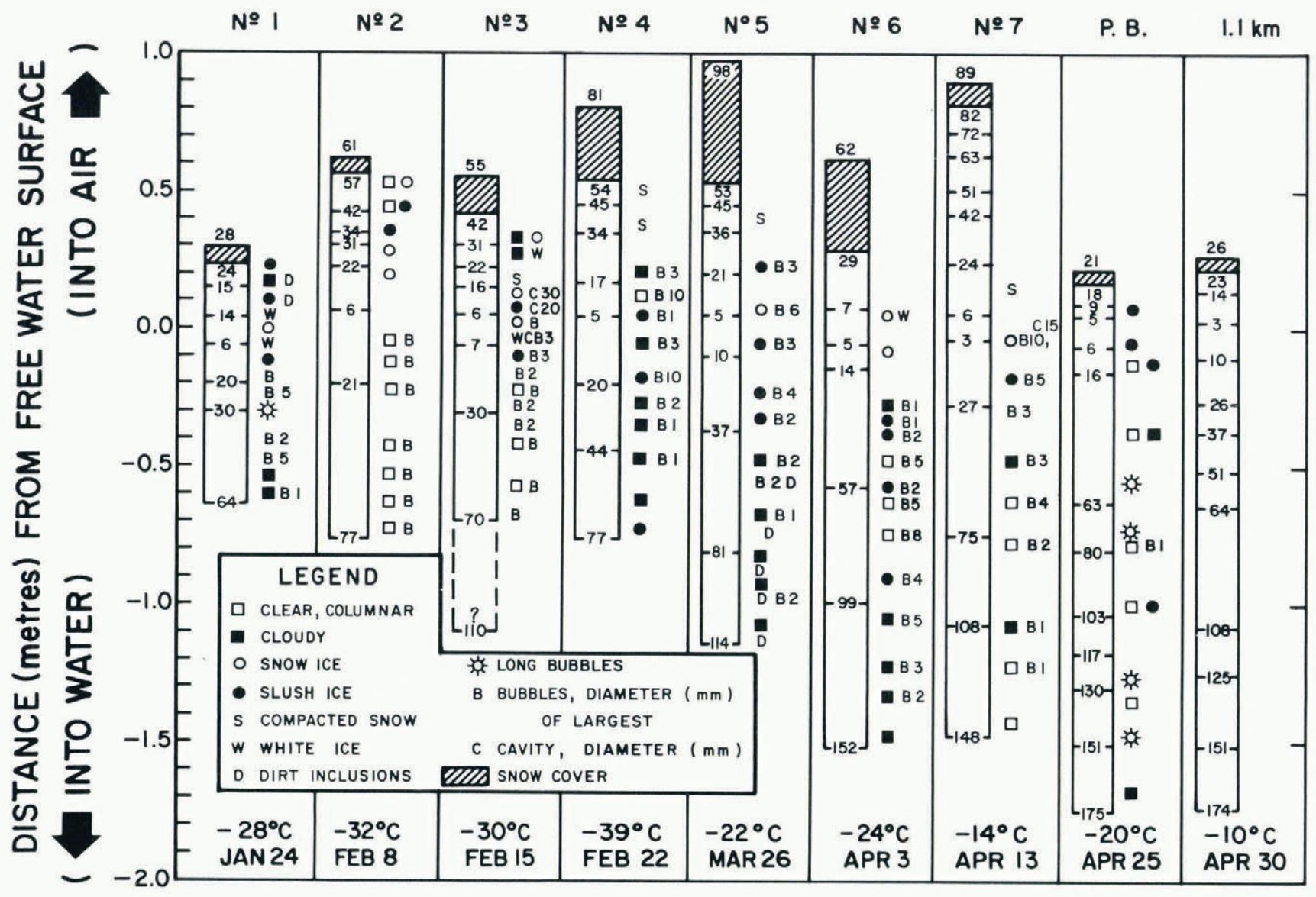

AIR TEMPERATURE AND DATE

Fig. 2. Visual characteristics of ice cores. Numbers on the cores indicate the distances of breaks from the free water suface, in centimetres. 
in a density measurement greater than might be expected for compacted snow.

The large differences in depth of snow cover and thickness of ice above the free water surface reveals the rafted nature of the ice. Core No. 5, for example, was taken from a location where snow had drifted between two rafts about $0.20 \mathrm{~m}$ thick. Core No. 3 shows a raft at about $0.30 \mathrm{~m}$ above water level, overlying a layer of compacted snow and snow-ice. The uppermost $0.6 \mathrm{~m}$ of core No. 7 were crumbly snow and were discarded without further examination. In marked contrast to this are the cores from smooth pans near Point Barrow and at the $1.7 \mathrm{~km}$ location west of NARL. These had a freeboard of only about $0.2 \mathrm{~m}$ and a snow cover of $30 \mathrm{~mm}$.

Just below the free water surface most cores contained slush-ice or snow-ice, probably a remnant of the stormy conditions which preceded the formation of the ice cover. Some of the cores contained brownish discolourations. These were thought at the time of examination to consist of silt stirred up during the stormy weather, but they (especially the one at the bottom of core No. 5) appeared very similar to the brown algae of the types recorded by Horner $\left(\left[{ }^{C} 1977\right]\right)$.

Despite efforts to extract the cores in long cylinders, breaks were frequent and are shown in Figure 2 by short horizontal lines and by numbers which indicate the distance in centimetres from the free water surface. Some of the breaks were probably due to torsional weakness in the ice, an example being the upper $0.6 \mathrm{~m}$ of core No. 7 . It may be significant that every core had a break 30 to $70 \mathrm{~mm}$ above the level of the free water surface, and those with slushice or snow-ice just below the free water surface broke 30 to $100 \mathrm{~mm}$ below that level. The lowest portion of core No. 3 could not be retrieved; its length was estimated to be $0.4 \mathrm{~m}$ although this could not be verified.

\section{Ice thickness}

The number of degree-days of frost can be approximated by using average daily temperatures recorded by the National Weather Service office in Barrow. Core lengths are shown in Figure 2. Figure 3 shows the thickness of ice plotted against the cumulative number of Celsius degree-days. 21 December was taken as the day on which the thickness and the number of degreedays begins; this date was ascertained by extrapolating backwards in time from the date on which the first core was taken (24 January). For the third core, two ice thicknesses are shown; these represent the actual length of core obtained and that length plus an estimate for the lower portion of the core which was lost. The correct value is probably bracketed by these two estimates.

The solid curve in Figure 3 is the parabola $y^{2}=$ $1.23 \times 10^{-3} \times$ chosen to give a best least-squares fit

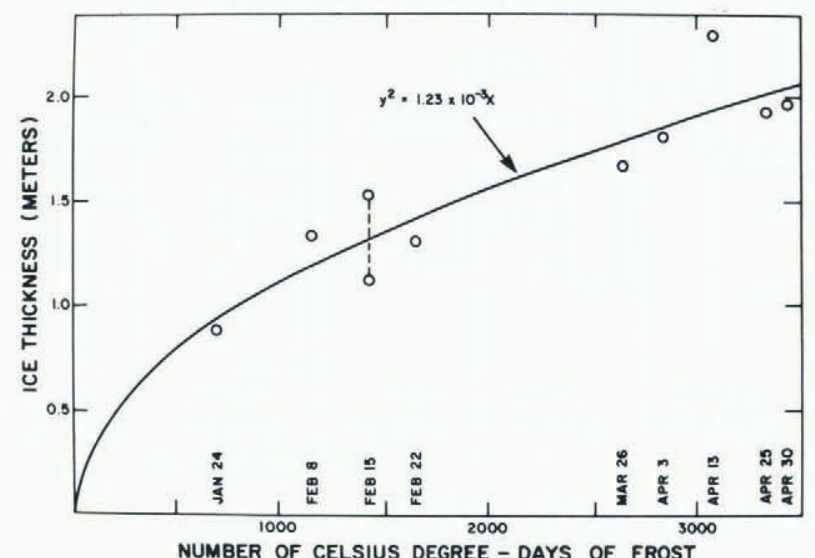

Fig. 3. Ice thickness versus degree-days of frost. to the points, and indicates that the ice thickness was reasonably proportional to the square root of the number of degree-days of frost, despite the irregular nature of the upper and lower surfaces of the ice and of the depth of the snow cover. Such a relationship was proposed as an engineering formula by Assur (1956) and recalled by Michel (1978, p. 32). A more exact treatment is discussed by Carslaw and Jaeger (1959, p. 282-96) and by Nakawo and Sinha (1981), but the conditions of the present study were too erratic for any treatment more exact than that of Assur.

\section{Salinity}

In Figure 4 the salinity $S$ in parts per thousand $(0 / 00)$ has been plotted against position in the ice cover for each core so studied, including one core extracted on 25 April from the Beaufort Sea as described earlier. From about $0.16 \mathrm{~m}$ below the free water

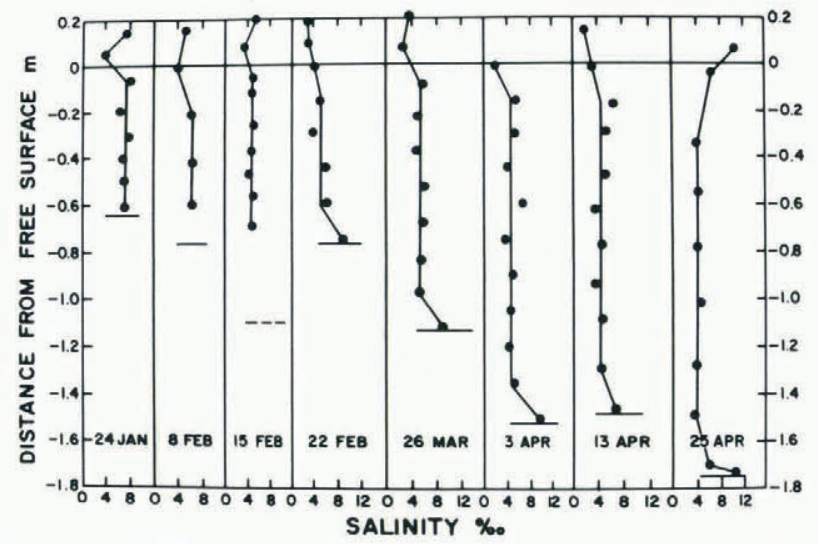

Fig. 4. Salinity of ice cores as a function of distance from the free water surface.

surface nearly to the bottom of the core the salinity was nearly constant, and a vertical line has been drawn to represent the mean salinity in this region. A higher salinity in the delicate skeletal layer at the bottom of the core can be seen in all but the first three cores, but it is likely that some of the brine had leaked out of these sections before they were packaged. To minimize brine loss, two sections were cut from the bottom of the 25 April core and stored in plastic bags as soon as possible after the core had been extracted. The salinity measurements for the bottom section was about 2.5 times greater than the mean salinity of the main section of the core. By April the upper part of the ice was warmer than the bottom, and this temperature gradient was aiding the gravitational force, promoting an increased rate of downward movement of the brine cells.

The core taken from the smooth ice field east of point Barrow shows a salinity greater than the mean value in the upper layers of the ice, as observed by Nakawo and Sinha (1981) and noted by Weeks and Ackley (1982). But all of the cores from the site near NARL show reduced salinity near the surface, although in many samples the uppermost sample used for salinity showed a higher brine content than that of the sample next below it, and the core taken on 13 April shows some increase of salinity at depths of $0.18 \mathrm{~m}$ and $0.30 \mathrm{~m}$. As has been shown in section 2, it appears that the rafted ice often lay over a layer of snow which, it may be presumed, either lay on the lower ice before rafting occurred, or drifted later into a gap left between the two layers. The thickness of ice rafts in the area was not generally measured, except that at one point the field book mentions two rafted pieces $0.20 \mathrm{~m}$ thick. It is likely that brine in the skeletal lower layer of the rafted pieces would seep into the layer of snow, freezing there into a snow-ice full of air bubbles but without the more regular vertically elongated brine cells found in conge- 
lation sea ice. This can explain the low (less than $4 \%$ ) salinity in upper sections of several cores, but it does not explain the lack of higher salinity in most of the upper sections. One possible explanation derives from the history of formation of the ice cover. The great quantity of slush seen moving just beyond the shore-fast ice during the storm on 29 December may have been clumps of floating snow or of chips formed by ice shear, but the conditions were ideal for formation of frazil. The properties of saline frazil have not yet been sufficiently investigated, but Hanley and Tsang (1984) have described properties of saline frazil which may indicate that it rejects solute more completely than congelation ice. Furthermore, the description of the ice presented in section 2 suggests that the first new ice formed in the region from which the cores were taken may have been consolidated slush; if the slush was either snow slush or frazil slush, this would explain a reduced salinity in the ice near the surface.

Figure 5 shows the mean salinities which were plotted as vertical line segments in Figure 2 . The point for 22 February represents the mean for only four measurements and appears anomalous. If this point is neglected, a straight line fitted to the remaining points shows a reduction in salinity by

0.0276 parts per thousand per day. Cox and Weeks

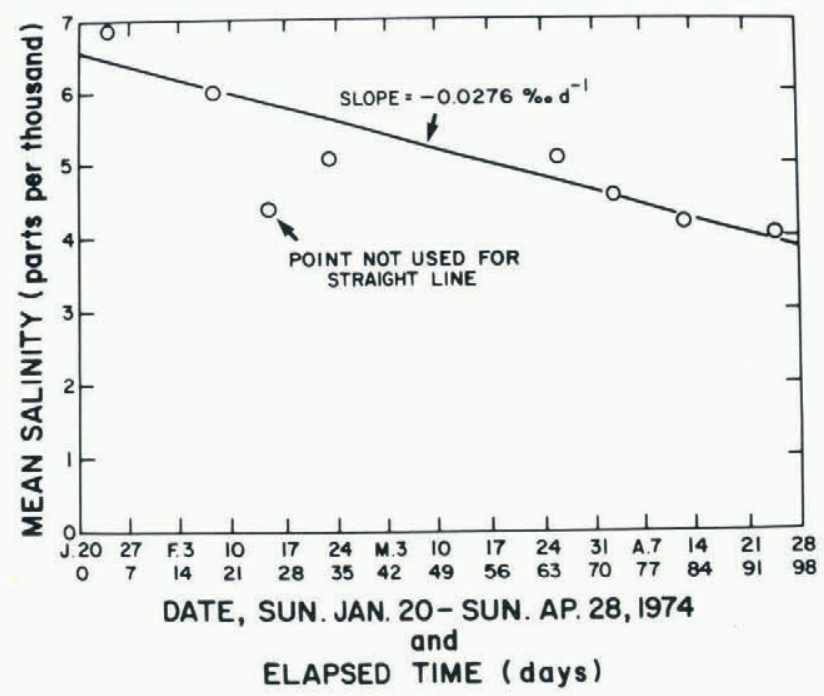

Fig. 5. Mean salinity as a function of time.

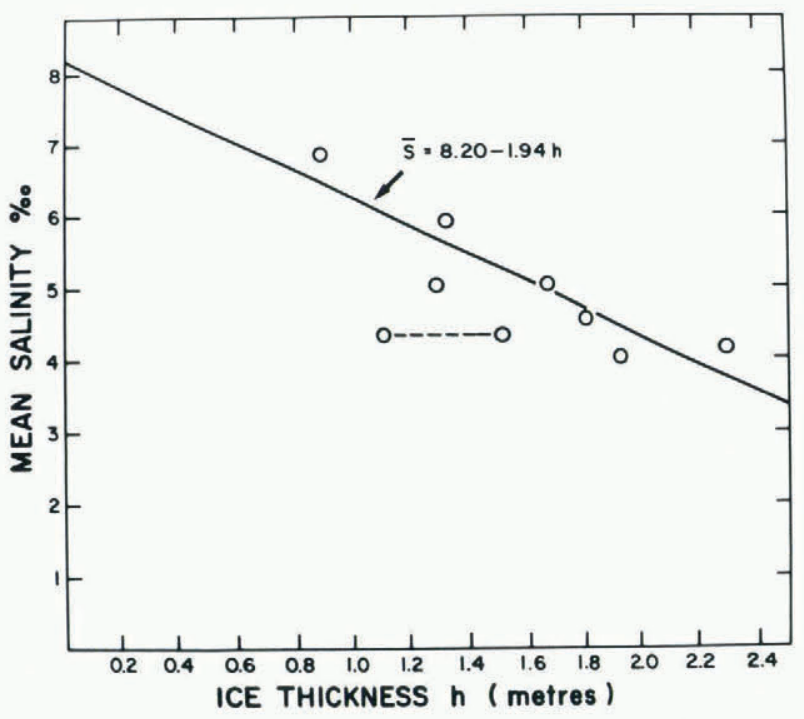

Fig. 6. Mean salinity as a function of ice thickness.
(1974) found a consistent relationship between average salinity and ice thickness. The corresponding graph is shown in Figure 6 . If the questionable points for 22 February are neglected, a least-squares fit yields the equation

$$
S=8.20-1.94 \mathrm{~h},
$$

which is close to the equation of Cox and Weeks, and indeed the points shown in Figure 6 fit very nearly within the standard deviation region of the plot by Cox and Weeks.

\section{Density}

The average density of a section of ice will depend on the constituents of the solute and the concentration of each constituent, the amount of air or other gases present in bubbles, and the presence and density of solid inclusions. The specific gravity of brine-ice and of mineral or organic particles is of the order of unity, whereas the specific gravity of air is about one thousandth of this. If the salinity does not vary by more than a few parts per thousand and if solid inclusions consist only of small amounts of mineral or organic matter, the presence of gaseous bubbles in the ice is likely to have more effect on the density than are the other factors.

There appeared to be no special trends showing in the densities for individual cores from NARL site, and so Figure 7 uses a single symbol for all points for these cores, with a different symbol for the core taken from the smooth ice field east of Point Barrow. The uppermost two sections cut from the latter core were cloudy and appeared to be consolidated slush ice, which apparently included air bubbles. The densities measured below the free water surface averaged $0.898 \mathrm{Mg} / \mathrm{m}^{3}$ with a standard deviation of $0.0038 \mathrm{Mg} / \mathrm{m}^{3}$; the variations are probably within experimental error, although it is tempting to see in them a C-shape in imitation of the salinity curve for this core.

The cores from the NARL site, in contrast, show a marked tendency toward lower density, and therefore

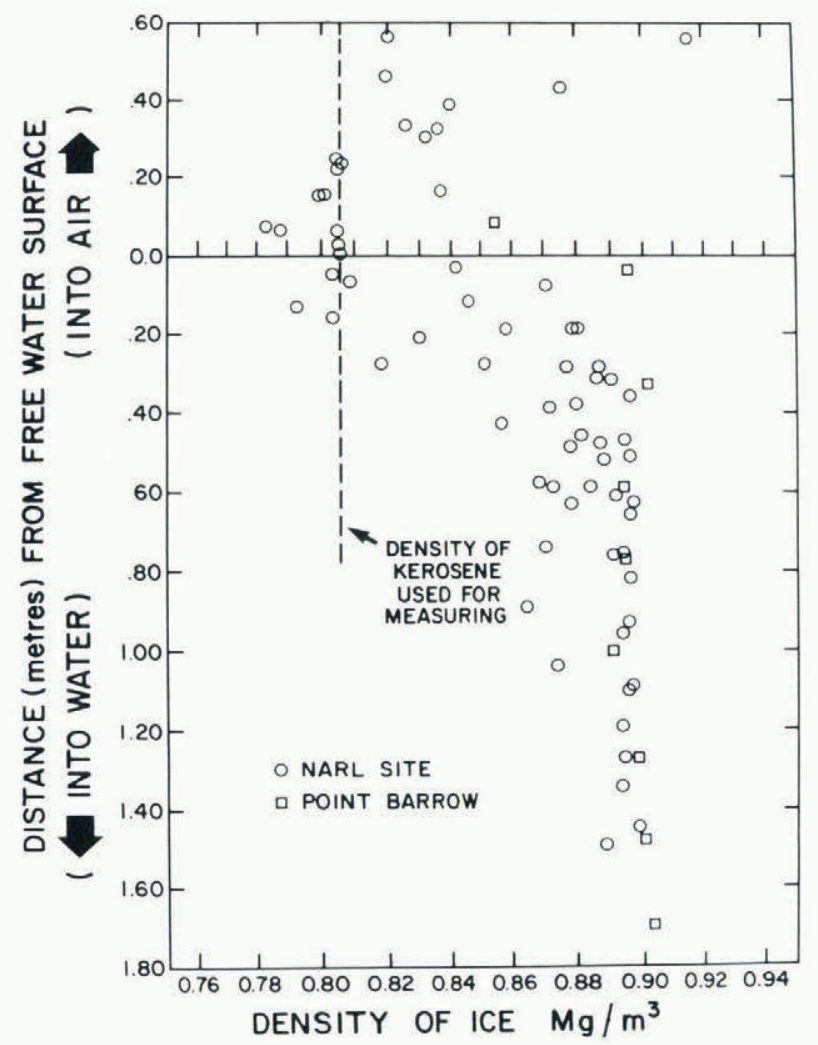

Fig. 7. Density of core sections for various distances from the free water surface. 
more air inclusions, as one looks upward toward the free water surface. The smallest density plotted $\left(0.738 \mathrm{Mg} / \mathrm{m}^{3}\right)$ belongs to the core taken on 8 February from a region of snow-ice or compacted snow; the neighbouring sections showed a low salinity of about $4 \%$ and also appeared to be slush-ice or partially consolidated snow. The point of least density below the free water surface $\left(0.793 \mathrm{Mg} / \mathrm{m}^{3}\right)$ belongs to the core taken on 3 April, and again was a section of snow ice.

\section{Temperatuce}

The temperatures indicated by the string of thermistors varied only slowly and uninterestingly until during the latter half of April it became clear that the upper layers of the ice would soon become warmer than the lower layers. As far as can be ascertained from the three thermistors embedded in the ice, the temperature varied nearly linearly with depth. Using temperatures recorded at midnight, the beginning of each day, for the reason that the air temperature at midnight is likely to be close to the mean temperature for that day, the downward temperature gradients have been plotted in Figure 8 for each day

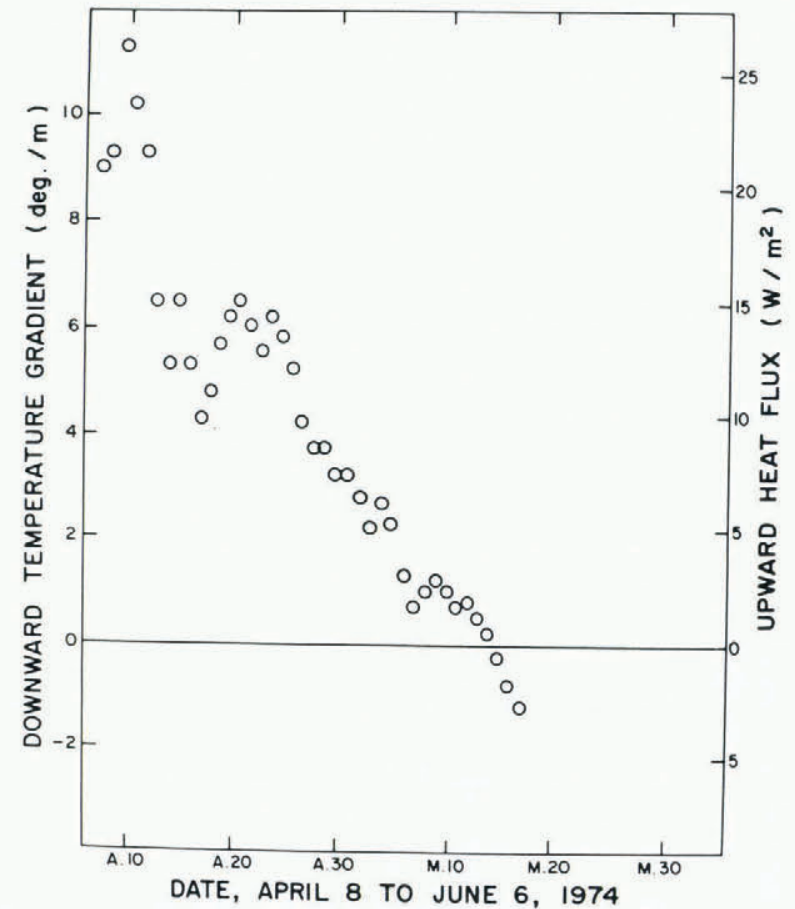

Fig. 8. Heat $\mathrm{fl}$ ux and reversal of temperature gradient in the ice droing May 1974.

from 8 April to 17 May and for 6 June. This shows clearly the change in sign of the gradient during the late spring.

Heat flow through the ice can be calculated from the equation

$$
Q=K d T / d y
$$

where $Q$ is the heat flow upward in $W / m^{2}, K$ is the thermal conductivity of the ice in $W /(m \mathrm{deg})$, and $\mathrm{dT} / \mathrm{dy}$ is the upward temperature gradient in $\mathrm{deg} / \mathrm{m}$. The thermal conductivity can be estimated by using the graphs of Ono (1968) as reported by Weeks and Ackley (1982). Ono treats thermal conductivity as a function of salinity and temperature. On the assumption that the linear relationship shown in Figure 5 can be extrapolated into June, the mean salinity diminished from $4.4 \%$ on 8 April to $3.2 \%$ on 17 May and $2.7 \%$ on 6 June. During this period the ice thickness grew from about $2.3 \mathrm{~m}$ to $3 \mathrm{~m}$. The thermistor at $0.80 \mathrm{~m}$ was closest to the mid-point of the ice thickness and recorded temperatures from $-9.1^{\circ} \mathrm{C}$ on 8 April to -5.0 on 17 May and -3.1 on 6 June. Ono's curves have very small slopes at $\mathrm{S}=3$ $\%$ from $-3^{\circ} \mathrm{C}$ to $-8^{\circ} \mathrm{C}$ and show an average value for the thermal conductivity $\mathrm{K}$ close to $2.3 \mathrm{~W} /(\mathrm{m} \mathrm{deg})$. This value of $K$ has been used to provide on the righthand side of Figure 8 a scale of values for the upward heat flux in $\mathrm{W} / \mathrm{m}^{2}$. It is clear that beginning on 14 May the net heat flow began to move from the atmosphere into the ice. Coincidentally, after 13 May the Sun at Barrow never sank below the horizon until late in July.

\section{CONCLUSIONS}

This paper has described several properties of near-shore ice in a piled and much-grounded field. Despite the irregular condition near the upper surface, the thickness as a function of time, the average salinity as a function of time and of thickness, and the temperature as a function of depth, all conformed to well-established patterns, although the standard deviations were large, as might have been expected. The density was fairly consistent at lower levels, but was very irregular near and especially above the free water surface, as a result of air bubbles included in the ice during the earlier days of consolidation. Many details in a visual description of the ice are characteristic of the stormy history of the formation of the ice cover.

\section{ACKNOWLEDGEMENTS}

The work presented in this paper was supported by the Alaska Sea Grant Program and by the Alaska $0 i 1$ and Gas Association. The study of ice cores described herein was suggested by Dr Thomas 0sterkamp, a member of the research team.

\section{REFERENCES}

Assur, A. 1956. Airfields on floating ice sheets for regular and emergency operations. U.S. Snow, Ice and Permafrost Research Establishment. Technical Report 36.

Carslaw, H.S., and Jaeger, J.C. 1959. Conduction of heat in solids. Second edition. 0xford, Clarendon Press.

Cox, G.F.N., and Weeks, W.F. 1974. Salinity variations in sea ice. Joronal of Glaciology, Vol. 13, No. 67, p. 109-20.

Hanley, T. O'D., and Tsang, G. 1984. Formation and properties of frazil in saline water. Cold Regions Science and Technology, Vol. 8, No. 3, p. 209-21. Horner, R.A. [ $\left.{ }^{C} 1977.\right]$ History and recent advances in the study of ice biota. (In Dunbar, Maxwell J., ed. Polar oceans. Proceedings of the Polar Oceans Conference held at McGill University, Montreal, May, 1974. Calgary, Alberta, Arctic Institute of North America, p. 269-83.)

Michel, B. 1978. Ice mechanics. Quëbec, Presses de l'Université Laval.

Nakawo, M., and Sinha, N.K. 1981. Growth rate and salinity profile of first-year sea ice in the High Arctic. Joumal of Glaciology, Vol. 27, No. 96, p. 315-30.

Ono, N. 1968. Kaihyō no netsuteki seishitsu no kenkyū. IV. Kaihyo no netsuteki na shoteisu. [Thermal properties of sea ice. IV. Thermal constants of sea ice]. Teion-kagaku: Low Temperatuce Science, Ser. A, [No.] 26, p. 329-49.

Weeks, W.F., and Ackley, S.F. 1982. The growth, properties, and structure of sea ice. CRREL Monograph (Hanover, N.H.) 82-1. 